\title{
The endangered unity of the family in the context of contemporary social changes
}

Man is a domestic creature. This means that a family has a profound meaning for the existence of humankind and the personal development of its individual members. A family community is based on the unity whose power is love. The emotional and spiritual unity is oriented towards the fulfilment of the emotional response on the part of other family members. ${ }^{1}$

The nature of contemporary social changes allows to hold on to the belief that this process significantly affects the condition of family life. Technical novelties that give rise to massive changes at a large scale leave an indelible mark

* Rev. Ireneusz Stolarczyk - a habilitated doctor of divinity and an associate professor of the Pontifical University of John Paul II in Krakow; a scholarship holder of the Catholic University of Bonn. He completed studies in sociology and social teaching of the Church at the Catholic University of Lublin. He gives lectures in Catholic social teaching as well as social and economic ethics in the Faculty of Theology, Section in Tarnów of the Pontifical University of John Paul II in Krakow, where he held the position of dean. An author of publications in social teaching of the Church, who in particular takes into consideration the evaluation of globalization and its impact on the existing structures of social life, culture and politics. In his publications, he also takes the subject connected with the interpretation of ethical and social rules worked out within the social teaching of the Church.

1 Cf. Cz. Strzeszewski, Katolicka nauka społeczna, Warszawa 1985, p. 398. 
also on the way of the contemporary social life and the style of relations within a family. An effect of the compression described as "world shrinkage" seems to play an important role here. The tools of communication and information sharing, enhanced for many years, have led these communities that used to have poor relations with each other to a unprecedented confrontation. The effect described as "world shrinkage" has led to exceptional communication between once distant localities. This is not without an impact on the style of family life.

The study below presents a negative influence of the world shrinkage on the shape of social life, thereby the unity of family. Changes of this type pose many challenges for families. Some of them are perhaps too difficult to keep their unity. In the first part, I will discuss problems connected with a threat to the unity of family due to processes of social polarization that increase tensions among members of social and family life. In this part, I will pay attention to a diversity of reasons that deepen the said divisions. The second part will debate on the influence of contemporary social changes on the disastrous process of erosion of social structures, the escape of elites and the loss of identity processes that impair the unity of family. This leads to well-founded fears in the social scale, which in turn contribute to the perception of contemporary social changes as the process that puts the stabilization and development of family at risk. This issue will constitute the third part of this study.

\section{A threat to the unity of family posed by the intensification of social divisions}

The said effect of the compression of the world means for individual local communities a characteristic liberation from time and space dependencies. Social dependencies occur where it has been difficult to determine their existence so far. During their occurrence, communities may perceive differences that in view of the existing territorial limitations have not even been noticed. The exterritoriality of contemporary social changes that destabilize the unity of family does not lead to the harmonization of social life but rather to its polarization. ${ }^{2}$ It appears that this phenomenon is one of

2 Bauman wrote about a new way of existence of a locality in the global reality: "The enslavement of time and space distances, thanks to technique, has polarized the human 
the more serious effects of an increased confrontation of forms of social life that is taking part owing to communication techniques.

The polarization may lead to the appearance of changes, such as differentiation, atomization and an increase of individualism - negative for society and the unity of family. ${ }^{3}$ This can mean that contemporary social changes will contribute to the maintenance of the social system which resembles the class system described by Domański: "On one side there are supporters of the concept of sustainability of social classes. They present society as a structured pattern of a clearly outlined hierarchy, on the top of which there are, separated from masses, elites, or (from the other point of view) 'upper classes', including the world of business and people of power, most privileged in access to material goods, culture and prestige. They surpass middle classes in an opportunity of control, in taking decisions and with regard to their standard of living (even though the latter also lack nothing to live a decent life and their representatives have no reason to complain), whereas the poor, the enclaves of poverty, the underclass occupy the lowest levels of the hierarchy. In this system, it is clear who is higher and who is lower. Barriers between individual steps of the social ladder are clearly defined and difficult to overcome." 4

Contemporary changes that, in the social dimension, give rise to polarization (having the nature of the atomization and social differentiation), can mean for social life a growth of characteristic "sources" of social divisions. ${ }^{5}$ The confrontation between the diversity of lifestyles, the amount of possessions or the level of education help to make comparisons between societies of the world, ultimately leading to the feeling of otherness and separateness. What has not been noticed or experienced so far because of the distance, is becoming a social problem that destabilizes the unity of family. The status of class separateness and difference, described by Domański,

condition rather than unified it. It therefore emancipates some individuals from territorial bonds and gives an exterritorial sense to some factors constituting the community [...]." Z. Bauman, Globalizacja, Warszawa 2000, p. 25.

3 Cf. H. Domański, Jak daleko do społeczeństwa rynkowego?, "Więź" 1992 nr 6, p. 48.

4 H. Domański, Demokracja teraz. Postmodernizm a struktura społeczna, "Społeczeństwo Otwarte" 1997 nr 12, p. 3.

5 Cf. B. Skrzydlewski, Dysproporcje gospodarcze i społeczne w świetle etyki życia międzynarodowego, "Zeszyty Naukowe Katolickiego Uniwersytetu Lubelskiego" 8 (1965) nr 2 (30), p. 30 . 
may take on - in the global scale - a negative tint, especially if the feeling of otherness has its source in differences in the amount of possessions ${ }^{6}$ and earnings.

One of the most perceptible examples of social polarization that is growing in the contemporary world is a strong feeling of economic inequalities. Some societies "find out" that their amount of possessions is disproportionally lower than that of other societies. ${ }^{7}$ Contemporary changes support seeing differences that - most likely - have not been determined so dramatically up till now. This is a trend that, if applied to family relations, does not support the unity of family. What is more, it seems that with appropriate efforts of investors, the said differences grow and evoke social disapproval and intrafamily problems. ${ }^{8}$ In this context, contemporary social changes appear as a process that does not help to eliminate differences and equalize living conditions of people across the world. ${ }^{9}$ This is rather a process that creates an opportunity to experience global inequalities and injustice. ${ }^{10}$ The feeling of inequality in possessions and earnings generates a lot of emotions. ${ }^{11}$

6 In the global scale, we can talk about mass poverty that causes dangerous social divisions: "This is the world of divisions of Western societies into the super-modern sector of transnational corporations with high income and a luxurious lifestyle, and the world of new, sometimes mass poverty - the world of ghettos of migrants who arrived at a later date, of neo-protectionism, hostility towards aliens, a revival of nationalist prejudices, ethnicity, moral relativity and even racism." E. Kośmicki, Globalizacja - próba diagnozy, "Dzišs" 1999 nr 12, p. 38.

7 Such a situation does not favour social unity and - as Martin and Schuman notice requires a democratic intervention: "The more the material inequality grows and the more dangerous it is for the internal cohesiveness of societies, the more important it will be that citizens themselves will defend their fundamental democratic rights and strengthen social solidarity. [...] Cooperation over borders and integration would be more able to punch its way out of a paper bag thanks to the involvement of millions of people in it. [...] It is good to think globally and act locally, however it is better to act together over borders." H. P. Martin, H. Schumann, Pułapka globalizacji. Atak na demokrację i dobrobyt, Wrocław 2000, p. 288. (Original title: Die Globalisierungsfalle. Der Angriff auf Demokratie und Wohlstand, Reinbek bei Hamburg 1996; English translation: The global trap: civilization and the assault on democracy and prosperity, London 1997).

8 Cf. A. Gwiazda, Globalizacja i regionalizacja gospodarki światowej, Toruń 1998, p. 159.

9 Cf. A. Wielowieyski, O duszę Europy, "Więż" 1995 nr 11, p. 21.

10 Cf. Cz. Strzeszewski, Współczesny kryzys rozwoju, "Ateneum Kapłańskie” 62 (1970) nr 1 (74), p. 24.

11 It should be noted that in literature on the subject, it is given that apart from the said differences in income, there are many more arguments against globalization: "Beyond this 
The clash between standards of living of societies in the world also leads to the reinforcement of the feeling of poverty. The effect is that the poor "are even poorer" and painfully feel it. The fact that the rich and the poor live in different worlds, do shopping, educate children and spend their leisure time in different places is, for the sake of social unity, accepted with difficulty. Social polarization, being an effect of contemporary changes, is noticeable on the rich v. the poor level, creating social and family divisions difficult to be done away with. The gap between these groups is growing. The process of the advancement of contemporary social changes is the factor that reinforces this growth. Sociologists emphasize that this is a very alarming state. The atomization and differentiation of societies, due to the identified and actually existing gap between the poor and the rich, has never been so obvious and acute. ${ }^{12}$ This is confirmed by reports that diagnose the spread of poor and affluent areas in the world as well as disproportions in received income among the world population. ${ }^{13}$ The demonstration of the high standard of living on television or during tourist travels can make that "where one's own country has nothing to offer but poverty, the young generation, hungry for life, sets out

general sense of disruption and dislocation, the opponents of globalization resent it because they [...] don't like the straitjacket because they feel economically pinched by it. Some worry that they don't have the knowledge [...]. Some don't like it because they resent the widening income gaps that the straitjacket produces [...]. Some don't like it because it opens them to all sorts of global cultural forces and influences [...]. Some don't like it because it seems to put a higher priority on laws to promote free trade [...]. In other words, the backlash against globalization is a broad phenomenon that is fed by many different specific emotions and anxieties." T. L. Friedman, The lexus and the olive tree. Understanding globalization, New York 2000, pp. 362.

12 Bauman notes that: "The division into the rich and the poor is nothing new; neither is it a momentary distress that with a due effort can be got rid of tomorrow or a bit later. However, the point is that for long the division has not been so explicit and absolute as it is today; and probably it has never been simply a division, not soothed by provision of mutual services and reciprocated dependency - a division whose parties have as much in common as a page of typescript with the content of a litter bin." Z. Bauman, Glokalizacja, czyli komu globalizacja, a komu lokalizacja, "Studia Socjologiczne" 1997 nr 3, p. 67.

13 Such a report is recalled by Dobrosielski in his article: "The newest UN Human Development Report of 1999 (UNDP) says that income of 200 richest people in the world is higher than the total revenue of 40 per cent (i.e. over 2 billion) of the poorest. 20 per cent of the global population who live in countries with the most developed economy have 86 per cent of the world's gross domestic product, and 20 per cent of the poorest - merely 1 per cent. Their income is in a similar range. Poor nations and people are more and more marginalized." M. Dobrosielski, Odpowiedzialność globalna, "Dziś" 1999 nr 10, p. 42. 
for promised lands." 14 In this sense, we can acknowledge that contemporary changes destabilize societies and weaken the unity of family.

The discussed process of the social atomization and differentiation, clearly noticeable in the context of social changes, applies also to unequal chances of participation in the process of collective social development. It is noticed that approximately $34 \%$ of the world population live outside the mainstream of the said process, out of which $20 \%$ gradually go away of it. ${ }^{15}$ This is a serious factor that differentiates the world population. Discrepancies in the consumption of economic goods as well as a strong diversification of opportunities to use blessings of the civilization create a social division affecting even families themselves. The growing trend, expressed in percentage units of people "dropping out" from the group of consumers of benefits stemming from worldwide transformations, makes social changes to be associated with dissatisfaction and the feeling of injustice and inequality. This leads to a growth in social and family antagonisms and conflicts. Social and family divisions of this type are emphasized both globally, i.e. between social groups remaining in the centre of the process, and inside groups that gain specific benefits from contemporary changes. The maintenance of the trends that diversify societies of the world and specific families in their access to consumption of benefits arising from changes of this type may end up with a state of a global chaos.

A strong polarization of social life applies also to diversified opportunities of using the Internet. Enhanced mass media are not yet accessible to all. In the scale of the world, they are used by a small group of people. This allows some sociologists to talk about wealth or poverty in an access to the knowledge entered into the memory of computers. The Internet contemporaneity, in the social dimension, creates a new category of people - the information-poor and the information-rich; the information-educated and the informationilliterate. Social stratification that emerges in this situation resembles divisions that became noticeable in the period of significant differences in the level of education of members of the same society and specific families. In the event of changes brought about by opportunities of ever-enhanced technique, it is not

14 H. P. Martin, H. Schumann, Pułapka globalizacji..., p. 51.

15 Cf. A. Zaorska, Ku globalizacji? Przemiany w korporacjach transnarodowych i w gospodarce światowej, Warszawa 1998, p. 244. 
only about the ability to read but also about an access to a computer network and an opportunity to acquire data. The onerousness of this state also involves the fact that the group which uses the computer network, quickly masters their skills and acquires necessary knowledge and expertise. Other members of society or families are shutting themselves in the world of ignorance - it is more and more difficult for them to meet the requirements of the world of digital reality, which are growing at an accelerating rate. In such a case, it seems extremely accurate to talk about the former group in the terms of "aristocracy of information society." Social polarization, caused by diversified access to electronic information, leads to hardly predictable consequences. ${ }^{16}$ No doubt it sparks off negative associations that contemporary processes of changes evoke.

It is worth recalling here the importance of equal chances in an access to contemporary scientific achievements. An access to the latest scientific and technological benefits is the mystery of the success of today's economy. For specific social groups and whole families, any diversification in an access to contemporary technologies, knowledge and technical achievements may mean backwardness in economic development. Knowledge capital decides about work efficiency, an increase of income and standards of living. For whole societies and members of specific families, inequality in an access to knowledge may turn out to be a characteristic disadvantage in economic development. Thus, any solution in which societies do not have equal chances of getting to electronic information deepens social polarization and weakens the unity of family through a possible slowdown of the local scientific and technical development.

16 Questions about the ultimate scenario of changes in the realm of public life, commenced by globalization, appear more and more often in contemporary publications: "The discerned technical and technological changes are closely connected with transformations in the area of science, finance, politics, economy, law, culture and education. These areas penetrate and condition each other, and the process of building information society has various unpredictable educational, social and personal consequences. I do not mean here a catastrophic vision. This trend was not unfamiliar to philosophers, scholars and writers, as early as at the beginning of $20^{\text {th }}$ century, who were concerned about the consequences of the development of the industrial revolution. [...] Today, Francis Fukuyama, an American philosopher and political scientist, talks about the end of history, asking a dramatic question about the sense of its creation." M. Tanaś, Cywilizacja globalna, społeczeństwo informacyjne a kształcenie, "Kultura i Edukacja" 1999 nr 1, p. 97. 


\section{A threat to the unity of family posed by changes in social relations}

Contemporaneous social changes may also affix another stigma, perhaps even more difficult in its consequences than the polarization trends described above, which can be noticed as the atomization and differentiation of the life of society and families. The effect of changes, defined as "world shrinkage" fosters the transformation of social bonds. Localities, so far closed in tight borders of geography and information, have been inviolable oases of stability with a strictly defined character of social interactions. Upon their opening to other societies, the process of freeing relations from restrictions of local communities, including a family, began. A public space, connected with a given territory, that has existed so far, is diminishing. Local societies are being "absorbed" by global society whereas the public space, with all the wealth of interactions created thereby, "is blending into" the space of worldwide society. Quick transmission of information as well as unlimited opportunities to travel have led to "[...] an erosion of all social and cultural 'wholenesses,' entrenched in their locality, and to their questioning; the process that for the first time was captured by Tönnies in his famous presentation of modernity as a shift from Gemeischaft to Gesellschaft." ${ }^{17}$ Resilience of communities, which existed before contemporaneous changes, involved the establishment of very strong internal connections, consolidated with borders difficult to be crossed that separate them from other local communities. Contemporaneity has made it easy to cross these borders. However, it has to be noted that the easiness of establishing new connections does not mean an automatic growth of communal relations in specific local communities. ${ }^{18}$ It may turn out that despite excellent means of communication, people can still be strangers to each other. For the unity of family, this process means the beginning of destructive changes.

17 Z. Bauman, Globalizacja..., p. 20.

18 This socially negative effect of globalization can be called a paradox: "One of the paradoxes of a world in which we are all increasingly connected is that it makes it that much easier for us all to become increasingly disconnected. Because the more we are all wired and networked together, the easier it becomes for each of us to work alone." T. L. Friedman, The Lexus and the olive tree..., p. 459. 
The said otherness can be also noticed in the event of a group of people who are an elite of cosmopolitans. Members of this group have great opportunities to take advantage of contemporaneous changes. This gives them a chance to become independent from territorially-restricted authorities, societies or individuals. Consequently, there is created a situation of impunity of elites who can escape responsibility, fleeing to the world or explaining failures and abuse by their helplessness towards an uncompromising diktat of social changes. Impunity of political or economic elites, who - this way - take advantage of global changes, weakens social and family life.

Many legitimate concerns about the nature of social and family life grow in the context of "difficulties with identity." The world of present changes has led to specific tensions between the global and the local. Localities and worldwideness are often in a clash. This applies not only to patterns of behaviour, standards, lifestyles or cultures but also to individual and group identities. The contemporaneity of social and family life is saturated with fear for the weakening of the identity or its total loss. ${ }^{19} \mathrm{~A}$ more or less legitimate fear for identities of individuals or groups translates into xenophobia, intolerance and separatism, and sometimes takes people to streets where the manifestation of reluctance to global changes takes a dangerously aggressive form.

It seems that the said problems with preserving personal, family and social identity are connected with peculiarities of changes in the social dimension and can mean both the process of drifting away from local identities, as far as breaking off any ties with the group of origin and moving to another group, and the process of weakening local identities as a result of a confrontation with the otherness and diversity in a global scale. The first effect, negative for one's identity, is defined as "eradication" of communities. Consequences of this process are mentioned by Kempny: "At the same time, it becomes equally important to consider the consequences of a potential characteristic 'eradication' of societies (in the meaning of making them free from territorial determinants) for the processes of shaping individual and collective identities. Territorial identities, typical for 'imagined communities', such as a nation or an ethnic group inhabitating a cohesive area, are called into question in the

19 Cf. K. Romaniszyn, Dylematy tożsamości europejskich pod koniec drugiego tysiąclecia, "Studia Socjologiczne" 1998 nr 3, p. 177. 
era of 'long-distance nationalism' and 'addressed media' transforming and affecting worlds experienced by individuals in such a way that the dichotomy between an individual and a territorially embedded society is questioned."20 Contemporary changes favour abandoning a territorially located community. ${ }^{21}$ Meanwhile, it is the territory on which specific communities and families lived where standards were established and personal relations, strengthening the family community and giving individuals and the whole group a defined identity, were built. The feeling of belonging to a group inhabitating a given territory fostered the feeling of individuality and held it together through the prevailing standards and habits. The identity established on the territory of residence of a given social group and individual families is getting weaker; upon leaving the place of residence, it losses its ability to shape individuals' consciousness. A lack of factors constituting human's identity is the most frequent problem of migration processes. Eradication of migrants from their old environments causes a shake of their identity, and consequently an accumulation of cultural, mental and custom-related problems. A feeling of being lost, connected with eradication from original environments and a lack of understanding and acceptance of the new setting, intensifies symptoms of frustration and insecurity. It also undermines the unity of family life.

Identity problems can also manifest in the form of the already mentioned process of weakening local identities as a result of a confrontation with the otherness and diversity in the global scale. More and more often the place of the confrontation is the Internet. Computer technology that brought about changes of the worldwide character is at the same time a threat to the maintenance of the identity of local communities and many families. The influence of the Internet turns out to be more powerful than the bonds

20 M. Kempny, Czy globalizacja kulturowa współdecyduje o dynamice społeczeństw postkomunistycznych?, "Kultura i Społeczeństwo" 2000 nr 1, p. 22.

21 Kempny pondered over the impact of this process on the condition of social life: "[...] a doubt arises whether the imposing vision of the evolution of the local community, according to which we can talk today about 'deterritorialization, 'a loss of any foundations,' 'de-centration,' 'destabilization' or 'de-essentialization' of culture, no longer anchored in any specific places, because of which culture advocates - 'eradicated' and 'homeless' - live as continuous 'en passant people' who cannot find anywhere their place on the earth, can be reconciled with the normative project of 'democratic consolidation' including a certain vision of a social order (or a newly established system in the state of quasi-equilibrium)." See: M. Kempny, Czy globalizacja kulturowa współdecyduje..., p. 20. 
holding together the locality and keeping it in a harmonious unity. In the Internet era you no longer have to leave the place of residence to lose the feeling of identification with the immediate environment and to drift away from a group of close friends. You may dwell in a specific place, yet feel connected with communities that are geographically very distant. Moreover, the Internet is the place of transmitting various information, including also the content that has a destructive impact on the fragile tissue of family life. This way, the Internet, described as the environment of chaos and anarchy, where you can publish and express whatever you feel like, appears to be an effective impediment in preserving the identity of its users. ${ }^{22}$ Readers of websites have difficulties in getting to up-to-the-mark, right-value content. The clash of values and the mentality of the environment in which they live, along with a chaos of the uncritical Internet milieu may result in a gradual weakening of the environmental identity, and ultimately in breaking fragile bonds of the community of living. The final effect of such a process can mean mental drifting of members of specific families, the breakdown of local ties and the atomization of social life.

At the present stage of social changes, it is difficult to determine unambiguously what will be the final outcome of the weakening of local identities. History reminds us that in the sphere of values we cannot take the liberty of leaving a specific "vacuum." The Internet, which is washing away more and more values that used to give local communities and whole families a unique charm and build their identity, must raise concerns. Pessimists forecast difficulties similar to those Europe was faced with when entering the industrial era. ${ }^{23}$ What is more, the process of social changes in the world makes us realize that the confrontation of values and identities of small groups is changing into the confrontation of values and identities of whole nations. Taylor, describing social changes in this dimension, even talks about a fight of national identities. That wording expresses a legitimate belief that

22 Cf. L. Głowiński, Między nowym totalizmem a nihilizmem aksjologicznym, "Więź" 1997 nr 2 (460), p. 18.

23 "Entering the industrial era was one of the most terrible periods in the history of Europe. When the old feudal lord allied with new capitalists and by means of a brutal government policy destroyed the traditional hierarchy of values and craftsmen's guild rules, and reduced customary laws of rural people to the miserable minimum, allowing a survival, they prepared not only poverty and suffering to millions of people." H. P. Martin, H. Schumann, Pułapka globalizacji..., pp. 272-273. 
contemporaneity may bring several new problems, among which the issue of the identity and unity of families makes its presence strongly felt.

\section{A threat to the unity of family posed by a growth of social fears and divergences}

Difficulties with the identity, typical for contemporary changes, pay attention to one more problem. Societies are afraid of losing their identity. An expression of this fear is the will to protect against a loss of identity, mentioned by Tanaś: "The bigger our awareness of the global reality, the more we try to protect our local identity." ${ }^{24}$ It is noted that the contemporary world lives in fear for global changes. It is worth recalling here that the source of this fear is in the effect described as an escalation of worldwide dependencies. Today's world is the world of Internet connections, cabling ${ }^{25}$ and the system that responds extremely quickly and efficiently. Contemporaneity endangers contemporaneity in the sense that in such an insular world a fear grows for coinhabitants of the same globe - for their decisions, reactions and plans. Each step of individuals, small groups or large communities evokes legitimate fears of others who - through the effect of dependency - experience consequences of decisions taken in other communities. ${ }^{26} \mathrm{~A}$ fear for others is augmented with the fact that an effective pattern of behaviours in such situations has not been worked out yet: "Human societies, living at a different speed and having extremely distinguishable levels of social experience, are bumping into each other without any warning or reflection. There are no protocols that could prepare us to such disorganised confrontations, there are no schools of social or collective behaviour." ${ }^{27}$ Such a situation makes a confrontation with otherness - taking place to such a degree and in such intensity - instil families' fear for security of living on the Earth.

It is worth noticing that the said fears develop both in particular families this is a fear for being dominated by the majority - and in large societies - a fear

24 M. Tanaś, Cywilizacja globalna..., p. 89.

25 T. L. Friedman, The Lexus and the olive tree..., pp. 401-517.

26 Cf. A. Pawełczyńska, Więzi społeczne w strukturach zła, "Ethos" 3 (1990) nr 9-10, p. 243.

27 M. Tanaś, Cywilizacja globalna..., p. 90. 
for onerous effectiveness of small groups and even particular individuals. ${ }^{28}$ While the first type of fear is already known - there have always been fears for bigger populations, the world population's fear for smaller (in number) groups, and even for particular individuals, is a hallmark of the newest changes in the realm of social life. The Internet, the already mentioned global cabling, and what stems from it, a growing inter-dependency at a global level, have created a situation in which the effectiveness of the activity of individuals or small groups is compared to the one of large populations. Based on that, the population of the world fears threats posed by small local societies that have nuclear weapons, for example. Similar fears are raised by small terrorist groups whose destructive activity may be experienced by an undefined local society. A fear for the "indetermination" of this type means that in the social dimension, contemporaneous changes may hold, in many world's inhabitants, negative associations destabilizing societies and contemporary families.

Finally, it is worth emphasizing that the effect of the world shrinkage typical for contemporary changes - intensifies the feeling of the divergence of objectives and the conflict of interests of individual local societies and particular families. The differences in the modality of life of families in individual world regions are becoming acute and receiving an expression. The paradoxes of social structures in the global dimension are even more noticeable. ${ }^{29}$ It is also more and more difficult to achieve unity in action, what Bauman expresses in the following diagnosis: "One of the most fateful consequences of the freedom of movement around the world is that it is more

28 Cf. J. Gaul, W stronę cywilizacji przyszłości, "Przegląd Powszechny” 1992 nr 11, p. 220.

29 "A global overview of social differences allows us to be convinced how many contradictions there are in the bosom of our civilization: Today, human rights of representatives of all classes, nations and races are acknowledged and at the same time we have plunged into unprecedented class struggles of nationalism and racism. These bad passions find an outlet in atrocities scientifically planned and committed in cold blood; both of these irreconcilably opposite states of spirit and ways of behaviour can be seen one next to the other not only in the same world but many times in the same country or even in the same soul. We also have unprecedented production capabilities and next to them unprecedented shortages. We have invented machines to work instead of us but we have never had such a shortage of labour serving man directly - even in such fundamental and elementary services as helping mothers look after children. We are permanently and alternatively accompanied by unemployment and a shortage of labour." A. Toynbee, Cywilizacja w czasie próby, Warszawa 1991, p. 104 (Original title: Civilization on trial, New York 1948). 
and more difficult to express social problems in the form of effective collective actions." ${ }^{30}$ We may therefore take the risk of saying that the contemporary world, in the social dimension, causes a lot of fear and destabilization and intensifies the feeling of injustice and the awareness of too big differences, which ultimately hinders the building of a climate of an "equitable dialogue" of whole societies and specific families.

\section{Bibliography}

Bauman Z., Globalizacja, Warszawa 2000.

Bauman Z., Glokalizacja, czyli komu globalizacja, a komu lokalizacja, "Studia Socjologiczne" $1997 \mathrm{nr}$ 3, pp. 53-69.

Dobrosielski M., Odpowiedzialność globalna, "Dziś" 1999 nr 10, pp. 40-46.

Domański H., Demokracja teraz. Postmodernizm a struktura społeczna, "Spoleczeństwo Otwarte" 1997 nr 12, pp. 3-9.

Domański H., Jak daleko do społeczeństwa rynkowego?, "Więź" $1992 \mathrm{nr} 6$, pp. $40-49$.

Friedman T. L., The lexus and the olive tree. Understanding globalization, New York 2000.

Gaul J., W stronę cywilizacji przyszłości, "Przegląd Powszechny” 1992 nr 11, pp. 215-226.

Głowiński L., Między nowym totalizmem a nihilizmem aksjologicznym, "Więź" $1997 \mathrm{nr} 2$ (460), pp. 14-19.

Gwiazda A., Globalizacja i regionalizacja gospodarki światowej, Torun 1998.

Kempy M., Czy globalizacja kulturowa współdecyduje o dynamice społeczeństw postkomunistycznych?, "Kultura i Społeczeństwo" 2000 nr 1, pp. 5-26.

Kośmicki E., Globalizacja - próba diagnozy, "Dziś" 1999 nr 12, pp. 29-40.

Martin H. P., Schumann H., Pułapka globalizacji. Atak na demokracje i dobrobyt, Wrocław 2000 (Original title: Die Globalisierungsfalle. Der Angriff auf Demokratie und Wohlstand, Reinbek bei Hamburg 1996, English translation: The global trap: civilization and the assault on democracy and prosperity, London 1997).

30 Z. Bauman, Globalizacja..., p. 83. 
Pawełczyńska A., Więzi społeczne w strukturach zła, "Ethos" 3 (1990) nr 9-10, pp. 229-246.

Romaniszyn K. Dylematy tożsamości europejskich pod koniec drugiego tysiąclecia, "Studia Socjologiczne" 1998 nr 3, pp. 175-179.

Skrzydlewski B., Dysproporcje gospodarcze i społeczne wświetle etyki życia międzynarodowego, "Zeszyty Naukowe Katolickiego Uniwersytetu Lubelskiego" 8 (1965) nr 2 (30), pp. 29-46.

Strzeszewski Cz., Katolicka nauka społeczna, Warszawa 1985.

Strzeszewski Cz., Współczesny kryzys rozwoju, “Ateneum Kapłańskie” 62 (1970) nr 1 (74), pp. 19-30.

Tanaś M., Cywilizacja globalna, społeczeństwo informacyjne a kształcenie, "Kultura i Edukacja” 1999 nr 1, pp. 87-111.

Wielowieyski A., O duszę Europy, "Więź" 1995 nr 11, pp. 21-28.

Zaorska A., Ku globalizacji? Przemiany w korporacjach transnarodowych $i$ w gospodarce światowej, Warszawa 1998. 